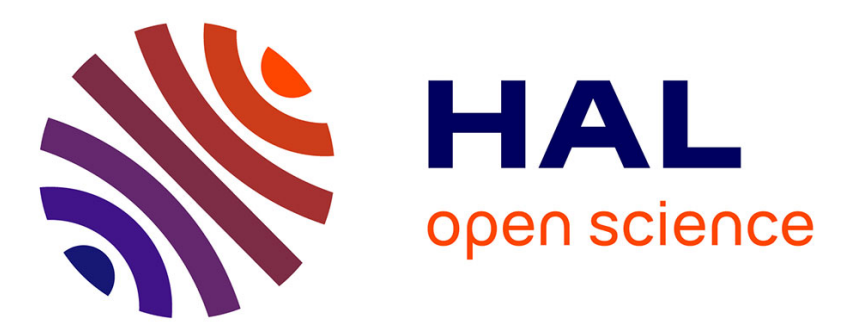

\title{
Climate-growth relationships for Aspidosperma tomentosum Mart. in South American tropical dry forests
}

Lidio López, Ricardo Villalba

\section{- To cite this version:}

Lidio López, Ricardo Villalba. Climate-growth relationships for Aspidosperma tomentosum Mart. in South American tropical dry forests. Annals of Forest Science, 2020, 77 (4), pp.96. 10.1007/s13595020-01001-8 . hal-03372625

\section{HAL Id: hal-03372625 \\ https://hal.science/hal-03372625}

Submitted on 11 Oct 2021

HAL is a multi-disciplinary open access archive for the deposit and dissemination of scientific research documents, whether they are published or not. The documents may come from teaching and research institutions in France or abroad, or from public or private research centers.
L'archive ouverte pluridisciplinaire $\mathbf{H A L}$, est destinée au dépôt et à la diffusion de documents scientifiques de niveau recherche, publiés ou non, émanant des établissements d'enseignement et de recherche français ou étrangers, des laboratoires publics ou privés. 


\title{
Climate-growth relationships for Aspidosperma tomentosum Mart. in South American tropical dry forests
}

\author{
Lidio López ${ }^{1}$ (1) $\cdot$ Ricardo Villalba ${ }^{1}$ \\ Received: 4 February 2020 / Accepted: 13 September 2020 / Published online: 9 October 2020 \\ (C) INRAE and Springer-Verlag France SAS, part of Springer Nature 2020
}

\begin{abstract}
- Key message The precise demarcation and cross-dating of tree rings in Aspidosperma tomentosum Mart., a valuable timber species in the tropical dry forests of South America, were used to develop the first well-replicated chronology covering the period 1843-2015. A. tomentosum Mart. tree growth is strongly regulated by soil water availability prior to and during the current growing season. In the context of increased drought severity due to climate change, determining of climate influences on $A$. tomentosum Mart. radial growth is necessary to establish appropriate guidelines for the management, conservation and restoration of this species, currently affected by extreme weather events, extensive fires and deforestation in the Chiquitanía forests, Bolivia.

- Context Tropical forest ecosystems play a critical role in the functioning of the Earth; thus, a better understanding of the influences of climate on tree growth is needed to estimate changes in forest productivity and consequently in carbon sink variations at regional and global scales.

- Aims In the context of global environmental changes, our study aimed at using the growth rings of A. tomentosum Mart. to establish the relationships between radial growth and climatic variations.

- Methods The anatomical characterization of the wood elements facilitated the precise annual band delimitation and the rejection of samples with false rings and growth anomalies. A tree-ring chronology was developed using traditional dendrochronological methods and the relationships with climate determined using correlation functions.

- Results The chronology is based on 20 individuals and covers the period 1843-2015. Tree-ring statistics indicate an important common signal in growth variations between trees $(\mathrm{R}-\mathrm{bar}=0.31, \mathrm{EPS}=0.90)$. Interannual variations in A. tomentosum Mart. are directly related to total annual precipitation $(r=0.76)$ and inversely to mean annual temperature $(r=-0.44)$. These relationships are similar to those documented for other commercial species (Centrolobium microchaete, Schinopsis brasiliensis) from tropical dry forests in South America, suggesting a consistent climatic influence on tree growth at a regional scale.

- Conclusion The strong dependence of tree growth on climate variability is a major concern, as climate change scenarios for tropical dry forests in South America predict an increase in the frequency and intensity of droughts, which in turn would reduce the A. tomentosum Mart. growth during the twenty-first century.
\end{abstract}

Keywords Dendrochronology $\cdot$ Tree rings $\cdot$ Climate change $\cdot$ Climate-growth relationships $\cdot$ Tropical dry forests $\cdot$ South America

Handling Editor: Cyrille B. K. Rathgeber and Patrick Fonti (Guest Editor)

This article is part of the topical collection on Wood formation and tree adaptation to climate

Lidio López

lopez@mendoza-conicet.gob.ar

Ricardo Villalba

ricardo@mendoza-conicet.gob.ar

1 Laboratorio de Dendrocronología e Historia Ambiental, Inst. Argentino de Nivología Glaciología y Ciencias Ambientales (IANIGLA), CONICET-Mendoza, C.C. 330,-

5500 Mendoza, Argentina

\section{Introduction}

The number of dendrochronological studies is increasing in tropical regions, incorporating new species and extending tree-ring records to new forest regions (Brienen et al. 2016; Lopez and Villalba, 2016a, b; Locosselli et al. 2017; Rahman et al. 2019). Initially, these studies were focused on determining the growth rates of few tropical tree species (Worbes and Junk 1999). More recently, the emphasis has been placed on searching for new species and determining their growth responses to climatic variations (Brienen and Zuidema 2005; Pumijumnong 2013; Brienen et al. 2016; Lopez et al. 2019). 
In the tropical region of South America, the number of treering chronologies developed from new species has increased significantly (Brienen and Zuidema 2005; Rozendaal and Zuidema 2011; Paredes-Villanueva et al. 2016; LaymeHuaman et al. 2018). However, despite the growing interest in using tree rings in tropical forests, to date, a very small percentage of tree species have been assessed dendrochronologically. Indeed, more than 200 different tree and shrub species per hectare have been recorded in tropical dry forests from South America (Jardim et al. 2003), suggesting that additional studies are required to provide a comprehensive view of the dendrochronological potential of these forests.

The lack of specific sampling tools for conducting dendrochronological collections from high-density tropical hardwoods has been a major constraint in the process of progressively incorporating new species and regions (Lopez and Villalba, 2016a, b). In this context, most dendrochronological collections in tropical forests are opportunistic, as samples have to be collected during forest harvesting, at the site of tree cutting or at the log collection and selection areas before being transported to the sawmills. Other limitations for tree-ring collections in the tropics are the accelerated process of wood decomposition, the low number of individuals of the same species per hectare and, in particular, the difficulties in accurately delimiting annual growth rings (Brienen et al. 2016; Rahman et al. 2019).

Despite the low percentage of tropical species examined for dendrochronological purposes, current results are very encouraging since tree-ring studies provide accurate and reliable information on tree growth and changes in a very short time (Brienen et al. 2016; Rahman et al. 2019). Indeed, recent research has answered many ecological and forest management issues such as stand mean ages, growth rate determination and the interval required by trees to reach a given diameter, among others (Brienen and Zuidema 2007; Lopez and Villalba, 2016a, b; Locosselli et al. 2017; Islam et al. 2018). Based on the rates of growth from tree rings, the biological rotation cycles and the amounts of wood expected to be collected in future harvests have precisely been estimated (Brienen and Zuidema 2006; Schöngart 2008; Lopez et al. 2013). In addition, the establishment of the relationships between variations in ring widths and precipitation or temperature has allowed to determine the dominant climatic conditions that modulate tree growth (Brienen and Zuidema 2005; Lopez and Villalba 2011; Mendivelso et al. 2014). This information can be used to estimate future rates of growth and the resilience of forests to the proposed twenty-first-century climate scenarios. Finally, proxy-climatic information generated from tree rings has also been successfully used to reconstruct rainfall variations over the last two centuries in various sectors of the Amazon Basin (Lopez et al. 2017; Granato-Souza et al. 2018) and to simulate the effect of $\mathrm{CO}_{2}$ fertilization on tropical tree growth (van der Sleen et al. 2015; Rahman et al. 2019).
In the current context of determining the dendrochronological potential of new species in tropical dry forests, we provide a dendrochronological assessment of Aspidosperma tomentosum Mart., a valuable timber species widely distributed in the tropical dry forests of South America. Currently, A. tomentosum Mart. is one of the species most intensively use for timber exploitation in tropical dry forests.

Based on the determination of the anatomical arrangement that defines the growth rings, the exact dating of the annual growth bands, and the precise measurement of the ring widths, we hypothesize that robust tree-ring chronologies from A. tomentosum Mart. could be developed in the tropical dry forests of Bolivia's lowlands. In addition, we postulate that by a careful comparison of the dendrochronological records with precipitation and temperature data, we can determine the growth response of this species to climatic variations. Finally, we anticipate that this relationship between climate and A. tomentosum Mart. tree growth will be comparable with those of other dominant species in the tropical dry forests.

\section{Methods}

\subsection{Study area}

The study area is located at San Julián, Bolivia $\left(16^{\circ} 51^{\prime} 48^{\prime \prime} \mathrm{S}\right.$; $62^{\circ} 30^{\prime} 52^{\prime \prime} \mathrm{W}$; Fig. 1), in the Llanuras de Santa Cruz botanical

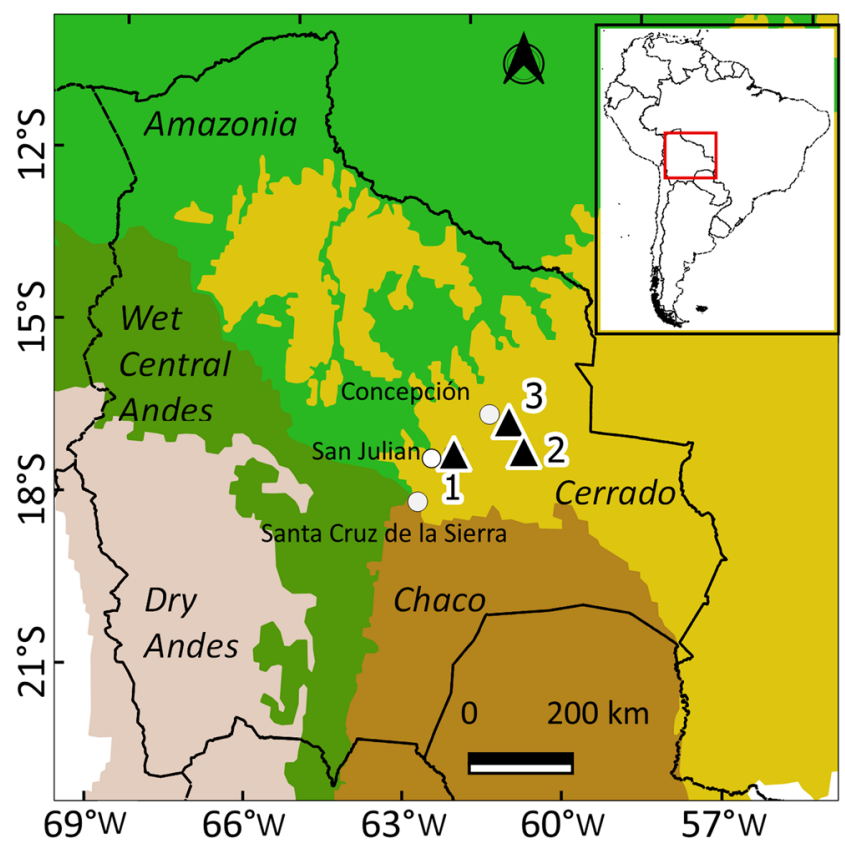

Fig. 1 Location map showing the Aspidosperma tomentosum sampling site (1) near the San Julián at the Llanuras botanical district, Santa Cruz, Bolivia. The Schinopsis brasiliensis (2) and Centrolobium microchaete (3) chronology sites, both located in the Chiquitano district, are also indicated 
district within the Cerrado biogeographic province (Navarro and Maldonado 2004). This phytogeographic province is one of the largest vegetation biomass in South America, extending from north-central Brazil to eastern Bolivia and northeastern Paraguay (Cabrera and Willink 1973). In Bolivia, the Cerrado province includes different forests from the transitional areas adjacent to the humid Amazon tropical formations to the swampy savannah of the Pantanal and the dry deciduous forests in the southern Bolivian Chaco (Killeen et al. 1993). The Llanuras (lowland plains) de Santa Cruz district, also included in the Cerrado, includes a territory characterized by open shrubby fields alternating with primary and secondary forests, typical of the seasonal rainy tropics. Most of the primary forests remaining in this district are dominated by species exceeding $20 \mathrm{~m}$ in height (Killeen et al. 1993).

Rainfall in the Llanuras de Santa Cruz district is concentrated mainly in summer. The dry winter season has a mean duration of 6 months from April to September (Fig. 2). The mean annual temperature at the San Javier, the closer meteorological station to the sampling area, is $24.1^{\circ} \mathrm{C}$ (period 1979-2016; Fig. 2). The total annual precipitation is $1406 \mathrm{~mm}(1979-2016)$.

\subsection{Species distribution}

In South America, the genus Aspidosperma (family Apocynaceae) includes eight species distributed across the tropical and subtropical dry forests from Peru and northcentral Brazil to northern Argentina (Killeen et al. 1993; Lorenzi 2002). Five species of Aspidosperma have been identified in Bolivia (Mostacedo et al. 2003). Aspidosperma tomentosum is present in the Chaco and Cerrado phytogeographic provinces in Bolivia, Brazil and Paraguay. It is a characteristic species of dry deciduous to semi-deciduous forests

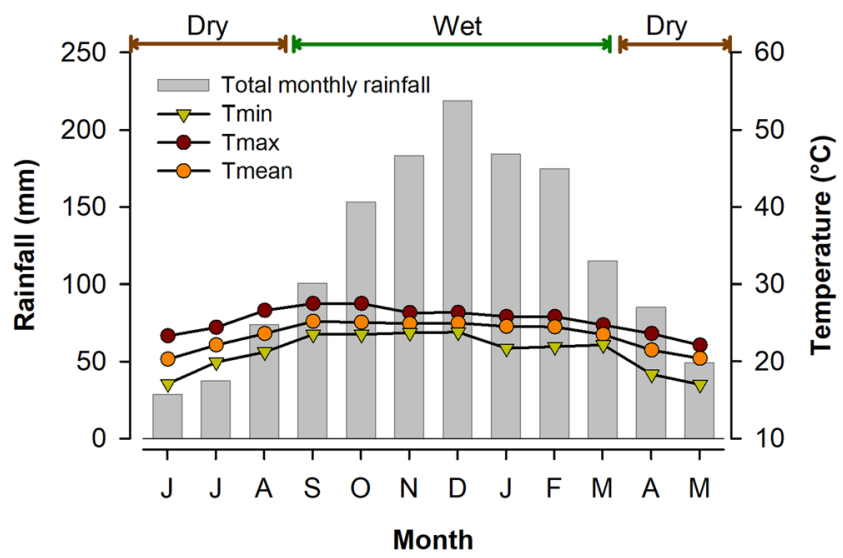

Fig. 2 Climatic diagram for San Javier weather station based on the period 1979-2016. The seasonal dry and wet periods are indicated at the top. The monthly mean, maximum and minimum temperatures and the monthly total precipitation are shown according to the hydrological year starting in July. Source: Servicio Nacional Meteorológico e Hidrológico de Bolivia (SENAMHI)
(Navarro 2011). Locally known as "Jichituriqui amarillo", A. tomentosum trees can reach up to $20 \mathrm{~m}$ in height and to 1 $\mathrm{m}$ in diameter (Mostacedo et al. 2003).

Aspidosperma tomentosum is a semi-deciduous, heliophytic or partially shade-tolerant species (Mostacedo et al. 2003). The wood is aromatic and hard with a mean wood density of $0.66 \pm 0.01 \mathrm{~g} \mathrm{~cm}^{-3}$; its main use is in furniture, housing construction, decorative objects and domestic utensils. A. tomentosum is also used as an ornamental tree.

\subsection{Sample collection}

The sample collection was conducted in the low-plain forests adjacent to the locality of San Julián, Nuflo de Chávez province, Santa Cruz, Bolivia (Fig. 2). Current intensive agricultural activities have reduced these forests to small fragmented patches (Killeen et al. 2008). In one of the clearing areas, cross sections from 48 trees were collected. These trees had previously been cut down and gathered at collection sites to be transported to local sawmills. Cross sections from A. tomentosum were taken at the lower and more circular part of the trunk. Before obtaining the cross sections, we registered for each individual the diameter and length of the stem and the health status of the trunk.

\subsection{Sample processing}

Cross sections were polished with progressively finer sandpaper (from 80 to 1200) to allow clear microscopic visualization of the minute wood anatomy (Fig. 3a). Tree rings were dated visually under a binocular microscope using a high-quality cold-type light. Samples were illuminated from different angles to achieve the best contrast in the wood. Following the Southern Hemisphere convention, annual rings were assigned to the year in which their formation began (Schulman 1956). The presence of growth anomalies (or growth lenses) is common in tropical species; these incomplete rings are the result of vascular activity in limited sectors of the tree circumference during part or the total annual biological cycle (Villalba 1987). In cross sections without the presence of growth lenses, two or more radii were cross-dated (Fig. 3b), and the ring widths measured with a precision of $0.001 \mathrm{~mm}$ using a Velmex UniSlide Tablet connected to a digital counter (Metronics Quick-Chek QC - 10 V).

\subsection{Chronology development}

The quality of the visual dating and the ring-width measurement was checked with the computer program COFECHA (Holmes 1983). This program calculates 


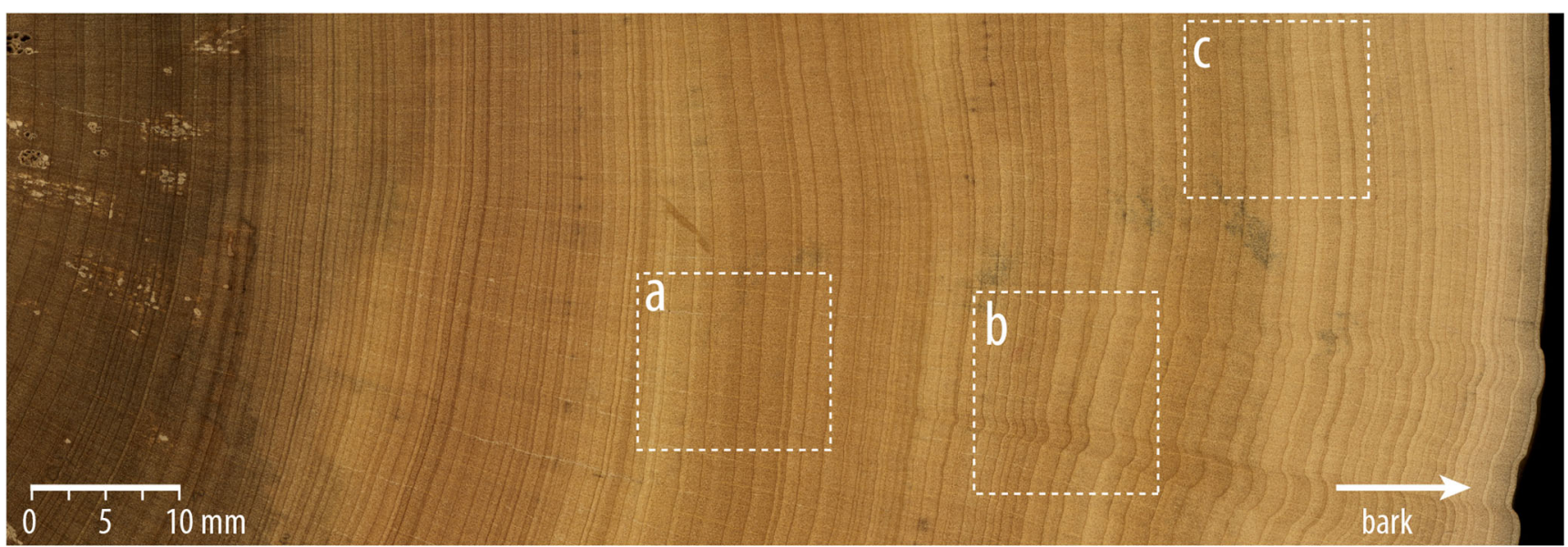

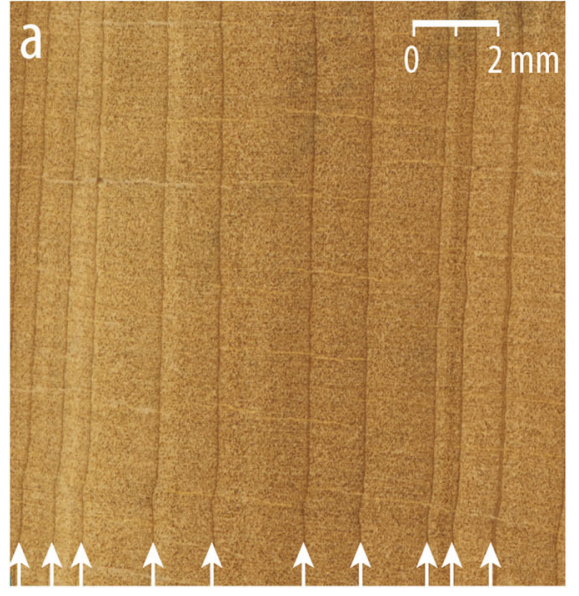

Fig. 3 Cross section views of Aspidosperma tomentosum wood. In the upper part, a cross section of $A$. tomentosum showing clearly distinct growth rings. Growth rings are demarcated by a band of compressed fibres at the end of each growth band. In the lower part, the upward

correlation coefficients between individual ring-width series and the master chronology by averaging all other dated samples at a particular site. This procedure helps to identify incorrectly dated specimens or segments and provides a statistical basis to help identify absent or false rings on the measured radii. Following the sample crossdating, all correctly dated series were standardized by fitting negative exponential curves or straight lines to the raw ring-width measurement time series using the program ARSTAN 0.41 (Cook and Holmes 1999; Cook et al. 2007). The objective of ring-width standardization is to remove long-term growth trends due to the increasing size and age of the tree, as well as to differences in the absolute growth rates among trees. In consequence, standardization maximizes the percentage of common variance in ring-width variations between samples in the chronology (Cook and Peters 1981; Cook and Holmes 1999). The standardized ring-width indices for each radius are dimensionless as a result of dividing the observed ring-width value by the value of the fitted curve in each year.
Several statistics used routinely in dendrochronology were calculated to estimate the quality of the derived chronology, including the standard deviation, the first-order autocorrelation and the mean sensitivity, a measure of the relative change in ring width from 1 year to the next, commonly related to growth responses to variations in climate (Fritts 1976). Other statistics used in dendrochronological studies, such as the Rbar and EPS, were also calculated. The R-bar is a measure of the common signal in tree-ring variations, calculated as the average correlation coefficient between all possible pairs of segments of a given length (50 years in our study) included in the chronology (Briffa 1995). The EPS (or expressed population signal) is a measure of the total signal present in the chronology (e.g., 50 years) in comparison with a fully replicated chronology. EPS values $>0.85$ indicate that the number of radii included in a particular segment of the chronology is large enough to capture an adequate percentage of the theoretical signal present in the fully replicated chronology (but see (Buras 2017)). EPS values $<0.85$ indicate that replication in that particular segment of the chronology is low and that the 
number of samples should be increased to strengthen the common signal (Briffa 1995).

\subsection{Climate-growth relationships}

In order to determine the climate influences on the growth of $A$. tomentosum, interannual variations in ring width were compared with monthly mean temperature and total precipitation records from the San Javier weather station using correlation function analysis (Blasing et al. 1984). This method estimates the correlation coefficients between ring-width indices and monthly climate variables. Because growth in a given year can be influenced by climatic conditions during the previous year, the comparison period used in our study included 21 months, from January during the previous growing season until May of the year in which the ring was formed. The common period between the A. tomentosum chronology and San Javier climate records is 1979-2015.

Finally, the spatial correlation patterns between the tree-ring variations in A. tomentosum and the temperature and precipitation fields were evaluated by estimating the correlation coefficients over the tropical-subtropical regions of South America based on the ERA-5 (Hersbach and Dee 2016) database using the facilities provided by KNMI-Climate Explorer (Trouet and Van Oldenborgh 2013) https://climexp.knmi.nl/start.cgi). The ERA-5 horizontal resolution is approximately $30 \mathrm{~km}$. Data for the 1979-2018 period was released in March 2019.

\section{Results}

\subsection{Wood anatomical characterization}

The wood of A. tomentosum shows light-brown and yellowish-brown colours in the heartwood and sapwood, respectively (Fig. 3a). The wood of A. tomentosum has diffuse porosity with numerous small vessels more abundant in the earlywood (Fig. 3b). After careful polishing, the growth rings are visible to the naked eye. However, a lens (10× or more) is required to precisely determine the tree-ring borders. Tree rings are demarcated by a thin continuous dark-brown band formed by the grouping of fibres at the end of the growth band. In some sectors of the cross section, it is common to see packages of semi-circular bands or compressed growth anomalies (Fig. 3c). These anomalous growth features make it difficult to date some samples correctly.

Growth-ring measurements in 24 radii from 20 individuals of $A$. tomentosum yielded a mean radial growth of $2.28 \mathrm{~mm} /$ year (173 years), reaching a mean maximum and minimum of $5.38 \mathrm{~mm}$ and $0.41 \mathrm{~mm} /$ year, respectively (Fig. 4).

\subsection{Chronology characteristics}

The chronology from A. tomentosum, which is based on 24 radii (20 from a total of 48 collected trees), covers the period 1843 2015 and is well replicated (> 10 trees) after 1886 ( Lopez and Villalba 2020). The statistics commonly used in dendrochronology to assess the quality of tree-ring records indicate that the A. tomentosum chronology is of good quality. A mean sensitivity value of 0.43 suggests a relatively high interannual variability in ring widths. This value is consistent with a standard deviation of 0.46 and a mean autocorrelation of 0.67 . In addition, the mean Rbar and EPS (1885-2015) for the whole chronology are 0.31 and 0.90 , respectively (Fig. 4). The chronology exhibits marked interannual variability in ring-width indices with periods dominated by low and high rates of growth. Periods with above-average tree growth are recorded from approximately 1880 until 1910 and particularly during the interval of 1980-2000. Belowaverage radial growth was registered for the intervals 1910 1930, 1940-1950, around the 1970s and after the year 2000. The above-average growth rates from 1880 to 1910 may be biased by the small sample size over this period (Fig. 4).

\subsection{Climate-tree growth relationships}

The radial growth of A. tomentosum is favoured by abundant rainfalls along the year (Fig. 5 upper). Radial growth is significantly related to precipitation in April at the end of the previous growing season and from August to January during the period of active tree growth. In contrast, radial growth is inversely related to temperature for most of the year, with significant correlation coefficients for the months of February and March during the previous year, and July, September, and from January to April during the current growing season (Fig. 5 upper).

Based on the correlation function results (Fig. 5), the interannual variations in the growth of $A$. tomentosum from San Julián were compared with the total annual precipitation (arranged from February of the previous growing season to January during the current growing season) from San Javier during the interval 1979-2015. Annual variations in precipitation explain about $58 \%$ of A. tomentosum growth $(r=0.76 ; p<0.01$, Fig. 6$)$. In turn, the $A$. tomentosum radial growth is significantly negative related to mean annual temperature (February to January) during the interval 1979-2015 ( $r=-0.44 ; p<$ $0.05)$. Higher temperatures during the growing season, concurrent in most cases with scarce rainfalls in spring and summer, increase evapotranspiration and reduce the soil water available for tree growth. 
Fig. 4 Annual ring-width variations per tree (grey lines) with the mean (black line, upper graph) and the standard tree-ring chronology (middle graph) from Aspidosperma tomentosum collected at San Julian, Santa Cruz, Bolivia. To emphasize the longterm variations, the chronology is shown with a cubic smoothing spline (red line) that highlights low-frequency variations over 15 years (Cook and Peters 1981). The variation in sample size over time is also shown in light grey. Finally, variations in the R-bar and EPS estimated over 50-year intervals are also shown for the interval 1900-2010 (lower graph)

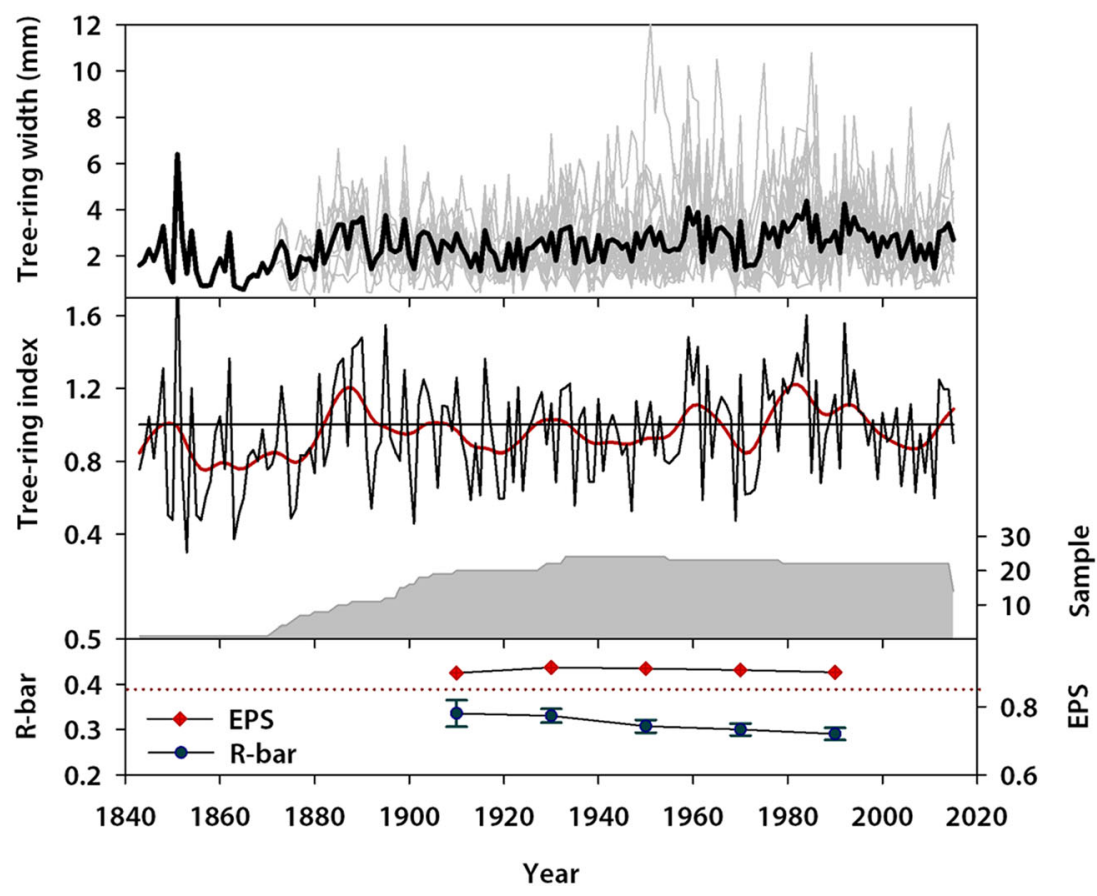

The climate-growth relationship recorded for A. tomentosum in the Bolivian Cerrado is consistent with the spatial patterns of correlation between the chronology and the precipitation and temperature data grids from ERA-5 (Hersbach and Dee 2016). The most significant spatial relationships with precipitation and temperature occur over or near the sampling site for A. tomentosum (Fig. 7). The correlation patterns are spatially more limited for precipitation, although it extends from central Brazil to north Paraguay. The significant pattern of spatial correlation between the tree-ring indices and temperature covers most of the southwestern Amazonia, indicating a
Fig. 5 Relationships between Aspidosperma tomentosum tree growth and San Javier climate from January of the previous growing season to April of the current growing season.

Correlations greater than $r=0.32$ (dotted lines) are statistically significant $(p<0.05$; period 1979-2015). The current growing season of $A$. tomentosum is highlighted. For comparison, the correlation functions of Schinopsis brasiliensis $(r>0.25$ statistically significant at $p<0.05$, 1943-2012) in San Miguel de Velasco and Centrolobium microchaete $(r>0.25$ statistically significant at $p<0.05,1943-$ 2011) in Concepción, both localities at the dry Chiquitano forest in Bolivia are shown (Lopez and Villalba 2011; Lopez and Villalba, 2016a, b)

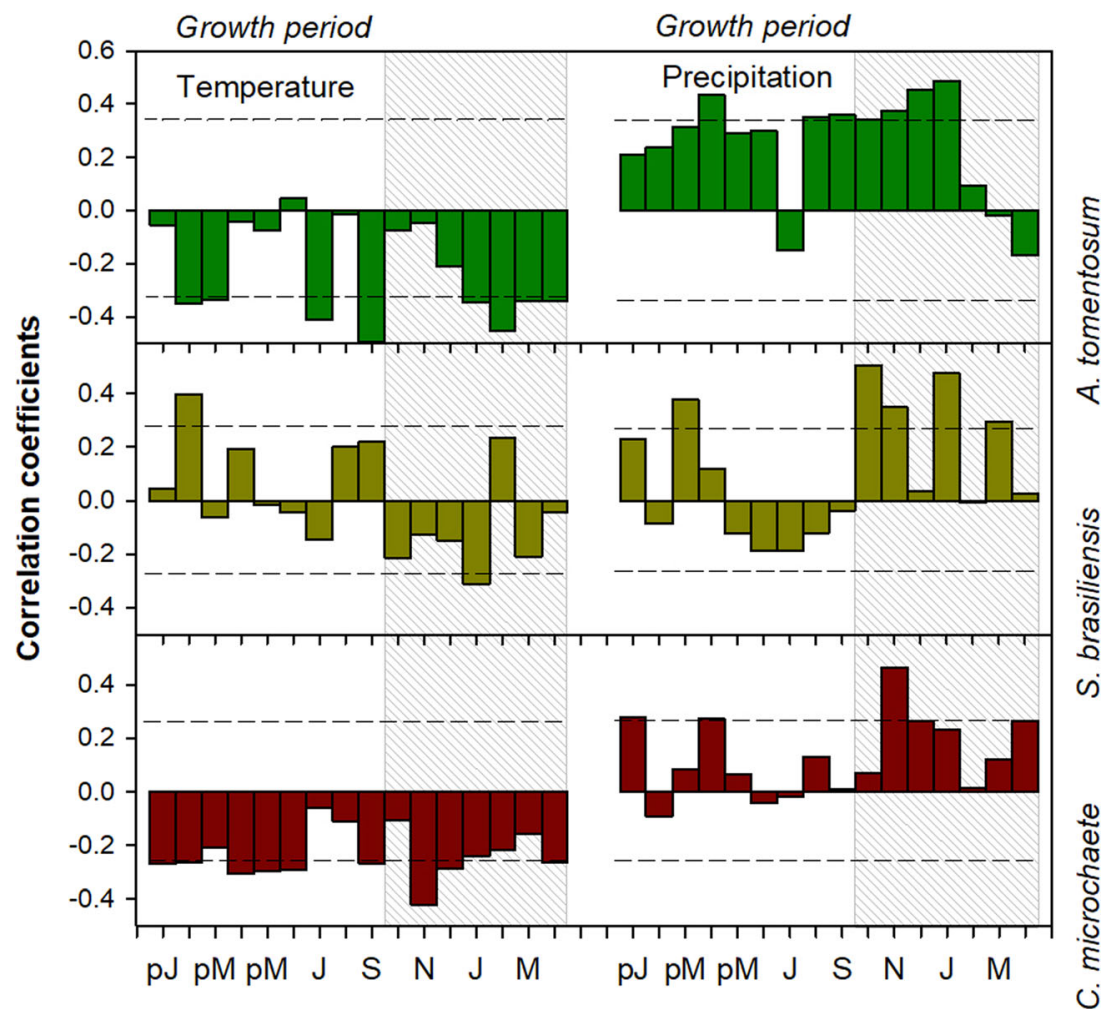


Fig. 6 Comparisons between interannual variations in the radial growth of Aspidosperma tomentosum at San Julian (green line) and annual (February to January) precipitation (blue line), temperature (red line) and SPEI

12 (orange line) along the period 1979-2015

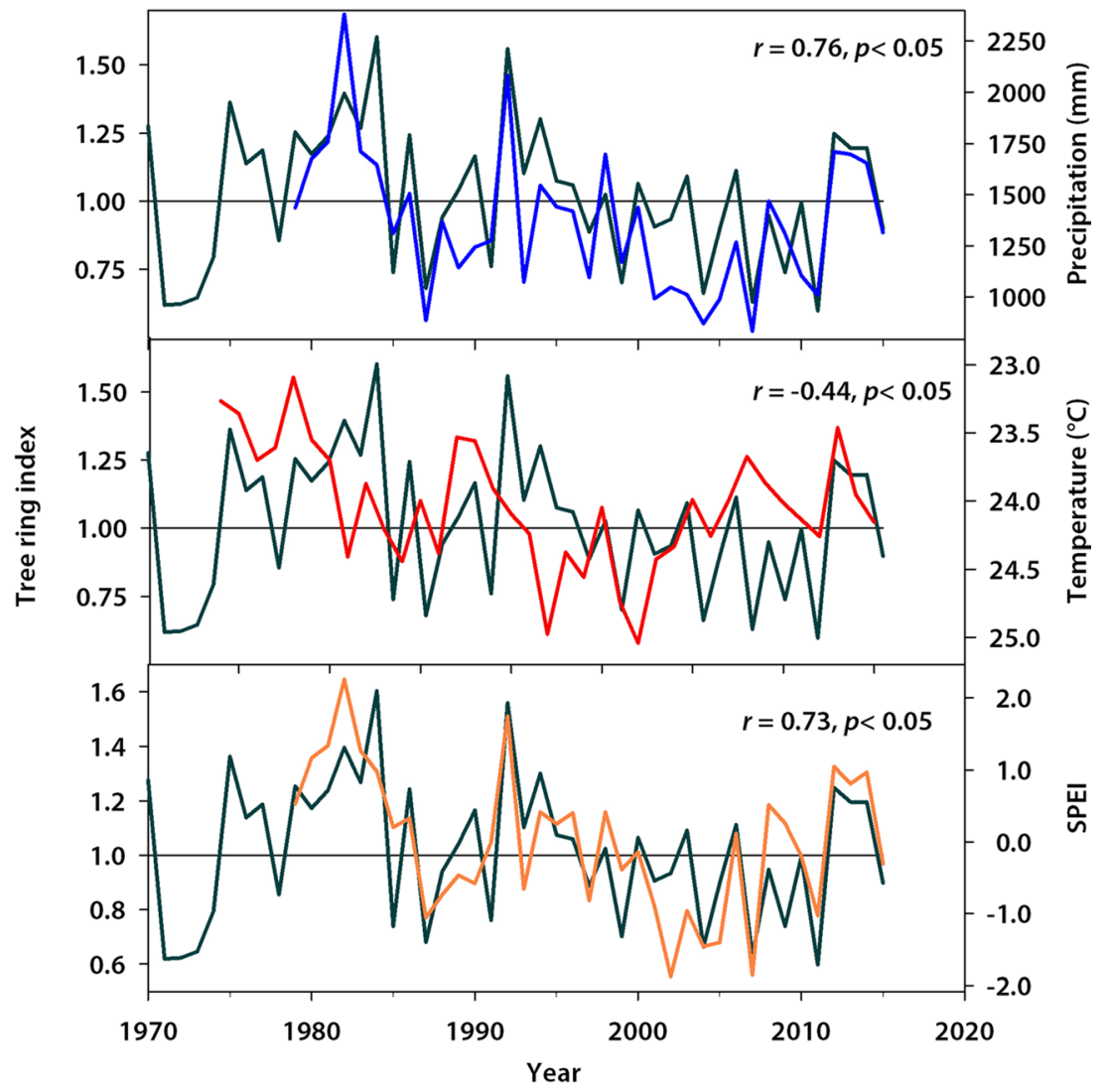

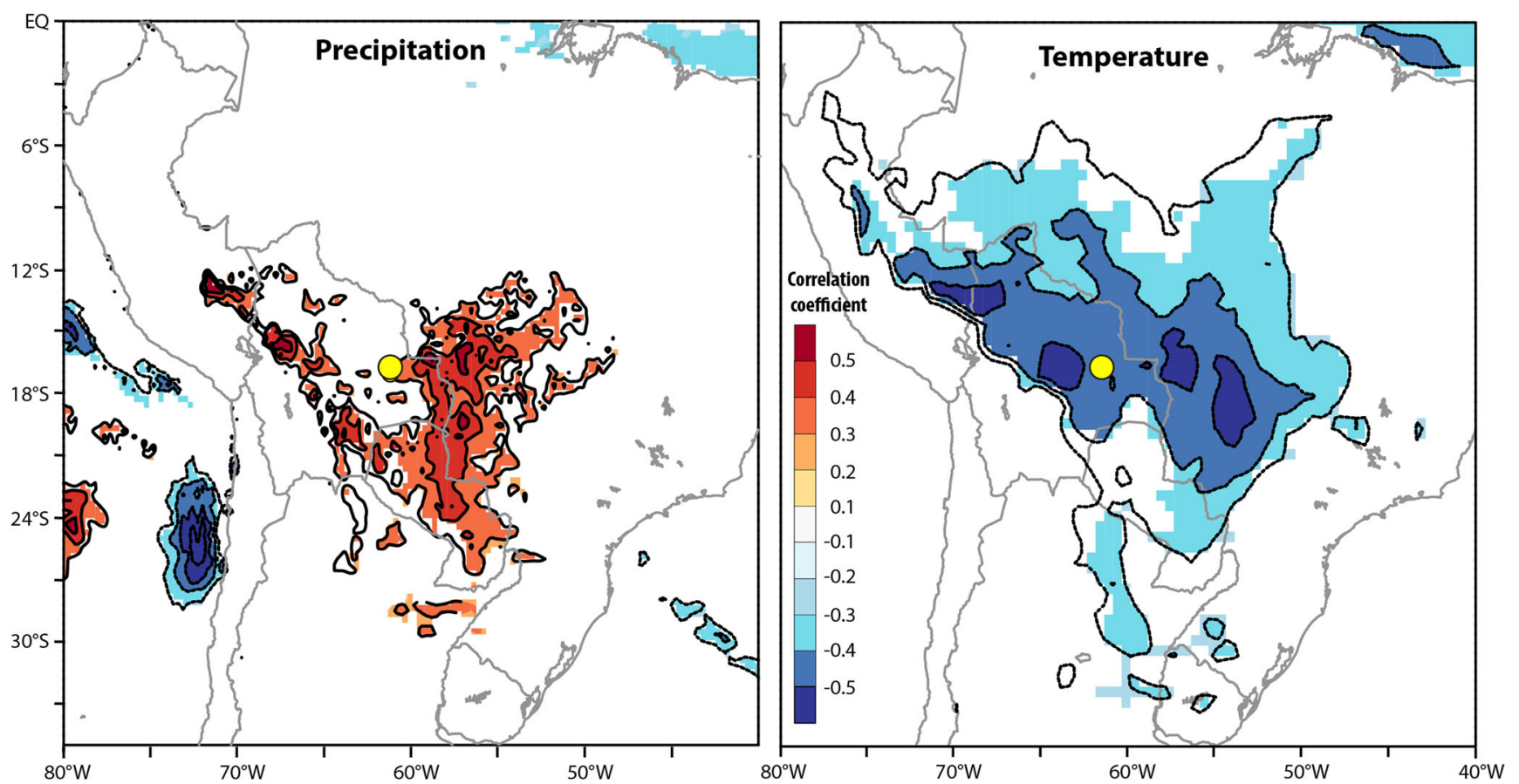

Fig. 7 Spatial correlation patterns between the A. tomentosum chronologies and gridded precipitation (left) and temperature (right) records from ERA-5 over tropical-subtropical regions in South America (EQ-30 $\left.{ }^{\circ} \mathrm{S}\right)$. The location of the chronology is indicated by a yellow circle 
more uniform spatial pattern of temperature than precipitation across the region (Fig. 7).

\section{Discussion}

\subsection{The Aspidosperma tomentosum chronology}

We employed a dendrochronological approach to advance in our understanding of the relationships between climate and Aspidosperma tomentosum radial growth. The first statistically reliable and well-replicated dendrochronological record of A. tomentosum from San Julián in the Llanuras botanical district, Bolivia, is presented here. Twenty-four radii from a total of 20 trees were used to develop a tree-ring-width chronology covering the period 1843-2015. Although previous studies report the existence of a chronology for this species, it is based on only eight individuals of $A$. tomentosum ranging in ages from 56 to 96 years (Mendivelso et al. 2013; Mendivelso et al. 2014). Growth lenses and false rings are frequently observed in cross sections of A. tomentosum (Fig. 2b). Growth lenses have already been reported for A. tomentosum at several sites in the Chiquitania district of the dry tropical forests (Lopez and Villalba, 2016a, b). These observations in Bolivia are consistent with (Vieira-Aragão et al. 2018), reporting frequent problems in dating Aspidosperma pyrifolium from Brazil due to frequent false or incomplete rings. Abrupt increases or decreases in the width of the rings, which impeded the cross-dating, were associated with the occurrence of growth lenses. Therefore, from a total of 48 trees, we selected a subset of 20 trees whose samples were properly cross-dated. Only samples without false rings or growth anomalies were cross-dated accordingly (Fig. 3).

The statistics traditionally used in dendrochronology indicate that the A. tomentosum chronology is of good quality and contains an important common signal in the radial growth of those trees that integrate the chronology. The mean R-bar for the A. tomentosum chronology is 0.31 , lower than the value reported for the Schinopsis brasiliensis (0.42) but similar to those for Centrolobium microchaete (mean of six records 0.31 ) chronologies (Lopez and Villalba 2011; Lopez and Villalba, 2016a, b) in the Chiquitano tropical dry forests. The EPS reaches 0.90 over the interval 1900-2010, indicating an adequate replication over this period. Similar EPS values have been reported for the Centrolobium microchaete (0.92-0.95) and S. brasiliensis (0.89) chronologies (Lopez and Villalba 2011; Lopez and Villalba, 2016a, b) in the Chiquitania district. The statistics reported by Mendivelso et al. (2014) from the preliminary chronology of $A$. tomentosum $(\mathrm{R}-\mathrm{bar}=0.23$ and $\mathrm{EPS}=0.86)$ are comparatively lower than those recorded in this study.

It is important to note that the A. tomentosum record presented here also represents the first tree-ring chronology developed in the Llanuras de Santa Cruz botanical district. Although the Llanuras district is part of the large Cerrado biogeographic province, it differs floristically from the Chiquitanía botanical district, in which most of the chronologies for tropical dry forest have been developed so far (Lopez et al. 2019). The Llanuras district vegetation has been profoundly altered by the recent expansion of agricultural activities substantially reducing the number of remaining forest patches. In the context of this accelerated expansion of human activities in the Llanuras, forest patches will be reduced in number and coverage, limiting the possibility of developing additional dendrochronological records in this tropical ecosystem.

\subsection{Climate and tree growth}

A comparison of year-to-year variations in the chronology with meteorological records indicates that A. tomentosum is highly sensitive to climatic variations, particularly to interannual changes in the water supply. The radial growth of A. tomentosum in the San Julián lowlands is largely modulated by water availability as indicated by the positive relationships with total annual precipitation and SPEI but negative with mean annual temperature (Fig. 6). Following the prolonged dry season, which extends over winter-early spring, precipitation from August to January is significantly related to A. tomentosum growth (Fig. 4). The radial growth of A. tomentosum is inversely related to temperature, both in the previous and current growing seasons. Significant negative relationships with temperatures were recorded during the months of February-March in the previous summer, July and September during the dry winter period and from January to April in the current growing season. Above-average temperatures increase evapotranspiration and reduce the soil water available for tree growth. Reduced growth in response to long-lasting droughts has been previously documented for several species in Bolivia's tropical dry forest (Mendivelso et al. 2014). Similar results have also been reported for the Brazilian dry forests. The interannual variability in A. pyrifolium growth rings in the xeric Caatinga, Brazil, responds positively to moisture conditions during spring and summer (Vieira-Aragão et al. 2018).

The relationships between the radial growth of $A$. tomentosum and the regional climatic variations identified in this study share similarities with those recorded for other emblematic tropical species in the Bolivian dry forests (Fig. 5). The radial growth of $A$. tomentosum is modulated by variations in annual precipitation, being highly significant during the end of the dry seasonbeginning of the wet season (August to January). The increase in rainfall at the end of the dry season gradually increases the moisture content in the soil and promotes the beginning of tree radial growth. Above-average temperatures increase the water deficit and reduce tree growth (Lopez and Villalba 2011; Lopez et al. 2019). This response pattern of $A$. tomentosum growth to climate is similar to those identified for other species in the Chiquitano dry forest. Several C. microchaete chronologies show that the 
growth of this species is directly related to precipitation from the end of the dry season to the beginning of the wet period. As in A. tomentosum, the relationships with rainfall are no longer significant after February of the current year (Lopez et al. 2019). We assume that high rainfalls in December and January, coincident with the peak of monsoon rains, saturate the soil moisture, so that rainfall from February to the rest of the wet season seems not extremely relevant for growth. In addition, the correlation function for Schinopsis brasiliensis, another Anacardiaceae family tree from the tropical dry forests, shows that the growth of this species is also directly associated with water availability from November (late spring) to January (Fig. 5; (Lopez and Villalba, 2016a, b). These similarities in climate-tree growth relationships support the concept of convergence in tree growth responses to climate in the tropical dry forests of South America (Lopez et al. 2019). According to these authors, growth responses to climate in the tropics are similar between sites with limited rainfall and prolonged dry seasons. The negative impact of scarce rainfall and marked seasonality on tree physiological processes seems to induce a convergence in tree growth responses to climate in tropical dry forests (Lopez et al. 2019).

\section{Conclusions}

Tropical forests are of enormous importance for the functioning of the entire planet. In addition to being a major global carbon sink, tropical forests are drivers of hydrological and climate processes on a continental scale (Bonan 2008; Pan et al. 2011; Spracklen et al. 2012). In this context, much effort should be devoted to understanding the influences of changing climatic conditions on tropical tree growth on mediumand long-term temporal scales.

Our study shows the possibility of developing well-replicated, two-century-long chronologies from Aspidosperma tomentosum in the tropical dry forests of South America. In addition, we demonstrated the possibility of extending the spatial coverage of tree-ring records in tropical dry forests. During the last two decades, most of the tree-ring chronologies in tropical dry forests have been developed in the Chiquitano district; hence, our chronology of A. tomentosum represents the first dendrochronological record for the Llanuras botanical district.

The radial growth of $A$. tomentosum is directly related to precipitation and inversely to temperature. Although these relationships persist throughout the year, they become statistically significant in the previous but particularly during the current growing season. The relationships of tree growth to climate documented for $A$. tomentosum are similar to those observed for other species in tropical dry forests, suggesting a convergence in tree growth responses to climate, as proposed by Lopez et al. (2019) for other species in dry tropical forests.
The A. tomentosum chronologies have an enormous dendroclimatic potential for reconstructing the variations in the summer monsoon system over tropical South America during the last two centuries or more. The correlation spatial patterns illustrated in Fig. 7 highlight the geographical representation of the climate signal captured by year-to-year variations in A. tomentosum tree rings and provide an indication of the species' dendroclimatic potential to reconstruct hydroclimatic variability in the tropical-subtropical regions of South America.

Given the strong dependence of tree growth on climate variations, projected increases in temperature and droughts in the region could negatively influence forest productivity in the tropical dry forests of South America during the twenty-first century. While these inferences about future tree growth reductions in Bolivia's dry forests are affected by the uncertainties associated with climate simulations and the limited number of studies on growth responses to climate in such diverse forests (Clark 2007), they do remain a concern. In addition, regional warming scenarios could be accelerated by the effects of extensive deforestation in the Amazon, intensifying and accelerating the projected $3-4.5^{\circ} \mathrm{C}$ increase in the temperature in the Bolivian Llanuras during this century (Urrutia and Vuille 2009). Rising temperatures will increase evaporation rates, aggravate water loss associated with declining precipitation and further reduce the growth of dry tropical forests (Lean and Warrilw 1989).

Acknowledgements Meteorological data were kindly provided by SENAMHI (Bolivia). The authors acknowledge the support of Inpa Parquet during field collections and thank Gualberto Zalazar, Pierre Pitte, Ignacio Mundo, Adalid Cuellar and Juan Carlos Gómez for helping with sample collection and processing. David Stahle helped with the preparation of the English version of this manuscript.

Contributions of the co-authors Conceptualization: Lidio López and Ricardo Villalba; methodology: Lidio López and Ricardo Villalba; software: NA; formal analysis: Lidio López and Ricardo Villalba; investigation: Lidio López and Ricardo Villalba; resources: NA; data curation: Lidio López and Ricardo Villalba; writing — original draft: Lidio López and Ricardo Villalba; writing - review and editing: Ricardo Villalba and Lidio Lopez; visualization: Ricardo Villalba and Lidio Lopez; supervision: Ricardo Villalba and Lidio Lopez; project administration: Ricardo Villalba; funding acquisition: Ricardo Villalba and Lidio Lopez.

Funding This study was funded by CONICET, Argentina and Foundation BNP Paribas

Data availability The datasets generated and/or analyzed during the current study are available in The International Tree Ring Data Bank repository at the NOAA Paleoclimatology Program, https://doi.org/10.25921/ 4nqs-t842 and upon request from the authors (lopez@mendoza-conicet. gob.ar).

\section{Compliance with ethical standards}

Conflict of interest The authors declare that they have no conflict of interest. 


\section{References}

Blasing TJ, Solomon AM, Duvick DN (1984) Response functions revisited. Tree-Ring Bulletin 44:1-15 http:/hdl.handle.net/10150/ 261260

Bonan GB (2008) Forests and climate change: forcings, feedbacks, and the climate benefits of forests. Science 320:1444-1449. https://doi. org/10.1126/science. 1155121

Brienen RJW, Schöngart J, Zuidema PA (2016) Tree rings in the tropics: insights into the ecology and climate sensitivity of tropical trees. In: Goldstein G, Santiago LS (eds) Tropical Tree Physiology. Springer International Publishing, Cham, pp 439-461

Brienen RJW, Zuidema PA (2005) Relating tree growth to rainfall in Bolivian rain forests: a test for six species using tree ring analysis. Oecologia 146:1-12. https://doi.org/10.1007/s00442-005-0160-y

Brienen RJW, Zuidema PA (2006) The use of tree rings in tropical forest management: projecting timber yields of four Bolivian tree species. Forest Ecology and Management 226:256-267. https://doi.org/10. 1016/j.foreco.2006.01.038

Brienen RJW, Zuidema PA (2007) Incorporating persistent tree growth differences increases estimates of tropical timber yield. Frontiers in Ecology and the Environment 5:302-306. https://doi.org/10.1890/ 1540-9295(2007)5[302:RCPTGD]2.0.CO;2

Briffa KR (1995) Interpreting high-resolution proxy climate data: the example of dendroclimatology. In: von Storch H, Navarra A (eds) Analysis of climate variability, applications of statistical techniques. Springer, Heidelberg, pp 77-94

Buras A (2017) A comment on the expressed population signal. Dendrochronologia 44:130-132. https://doi.org/10.1016/j.dendro. 2017.03.005

Cabrera AL, Willink A (1973). Biogeografia de América Latina., 120 pp. OEA (Organización de los Estados Americanos), Washington, DC

Clark DA (2007) Detecting tropical forests' responses to global climatic and atmospheric change: current challenges and a way forward. Biotropica 39:4-19. https://doi.org/10.1111/j.1744-7429.2006. 00227.x

Cook ER, Krusic PJ, Holmes RH, Peters K (2007). Program ARSTAN, version 41d, 2007. www.ldeo.columbia.edu/tree-ringlaboratory, 84 pp, Tree-ringlaboratory

Cook ER, Peters K (1981) The smoothing spline: a new approach to standardizing forest interior tree-ring width series for dendroclimatic studies. Tree-Ring Bulletin 41:45-53 http:// www.treeringsociety.org

Cook RE, Holmes RL (1999) Users Manual for Program Arstan, 16 pp. Laboratory of Tree-Ring Research, University of Arizona, Tucson

Fritts HC (1976) Tree rings and climate, 567 pp. Academic Press, London Granato-Souza D, Stahle SW, Barbosa AC, Feng S, Torbenson MCA, Assis Pereira G, Schöngart J, Barbosa JP, Griffin D (2018) Tree rings and rainfall in the equatorial Amazon. Climate Dynamics 50: 1-13. https://doi.org/10.1007/s00382-018-4227-y

Hersbach H, Dee D (2016) ERA5 reanalysis is in production. ECMWF Newsletter 147:7 https://www.ecmwf.int/en/newsletter/147/news/ era5-reanalysis-production

Holmes RL (1983) Computer-assisted quality control in tree-ring dating and measurement. Tree-Ring Bulletin 43:69-78 10150/261223

Islam M, Rahman M, Bräuning A (2018) Growth-ring boundary anatomy and dendrochronological potential in a moist tropical forest in Northeastern Bangladesh. Tree-Ring Research 74(1):76-93. https://doi.org/10.3959/1536-1098-74.1.76

Jardim A, Killeen TJ, Fuentes A (2003). Guía de los Árboles y Arbustos del Bosque Seco Chiquitano Bolivia, , 324 pp. Fundación para la conservación del Bosques Chiquitanos (FCBC), FAN, Santa Cruz de la Sierra, Bolivia
Killeen JT, Garcia E, Berck GS (1993). Guía de arboles de Bolivia. Herbario Nacional de Bolivia, Missouri Botanical Garden, 958 pp. Quipus S.R.L, La Paz

Killeen TJ, Guerra A, Calzada M, Correa L, Calderon V, Soria L, Quezada B, Steininger MK (2008) Total historical land-use change in eastern Bolivia: who, where, when, and how much? Ecology and Society 13:1-36. https://doi.org/10.5751/ES-02453-130136

Layme-Huaman E, Ferrero ME, Palacios-Lazaro KS, Requena-Rojas EJ (2018) Cedrela nebulosa: a novel species for dendroclimatological studies in the montane tropics of South America. Dendrochronologia 50:105-112. https://doi.org/10.1016/j.dendro. 2018.06.004

Lean J, Warrilw DA (1989) Simulation of the regional climatic impact of Amazon deforestation. Nature 342:411-413. https://doi.org/10. $1038 / 342411 \mathrm{a} 0$

Locosselli GM, Krottenthaler S, Pitsch P, Anhuf D, Ceccantini G (2017) Age and growth rate of congeneric tree species (Hymenaea spp. Leguminosae) inhabiting different tropical biomes. Erdkunde 71(1): 45-57. https://doi.org/10.3112/erdkunde.2017.01.03

Lopez L, Rodríguez-Catón M, Villalba R (2019) Convergence in growth responses of tropical trees to climate driven by water stress. Ecography 42:1-14. https://doi.org/10.1111/ecog.04296

Lopez L, Stahle D, Villalba R, Torbenson M, Feng S, Cook E (2017) Tree ring reconstructed rainfall over the southern Amazon Basin. Geophysical Research Letters 44:7410-7418. https://doi.org/10. 1002/2017GL073363

Lopez L, Villalba R (2011) Climate influences on the radial growth of Centrolobium microchaete, a valuable timber species from the tropical dry forests in Bolivia. Biotropica 43:41-49. https://doi.org/10. 1111/j.1744-7429.2010.00653.x

Lopez L, Villalba R (2016a) An assessment of Schinopsis brasiliensis Engler (Anacardiacea) for dendroclimatological applications in the tropical Cerrado and Chaco forests, Bolivia. Dendrochronologia 40: 85-92. https://doi.org/10.1016/j.dendro.2016.07.002

Lopez L, Villalba R (2016b) Reliable estimates of radial growth for eight tropical species based on wood anatomical patterns. Journal of Tropical Forest Science 28(2):139-152 org/stable/43799217

Lopez L, Villalba R, Bravo F (2013) Cumulative diameter growth and biological rotation age for seven tree species in the Cerrado biogeographical province of Bolivia. Forest Ecology and Management 292:49-55. https://doi.org/10.1016/j.foreco.2012.12.011

Lopez L, Villalba R (2020) Dataset for "Climate-growth relationships for Aspidosperma tomentosum in South American tropical dry forests". NOAA National Centers for Environmental Information. https:// doi.org/10.25921/4nqs-t842. Accessed 2020-08-28

Lorenzi H (2002) Árvores brasileiras: manual de identificação e cultivo de plantas arbóreas nativas do Brasil, 384 pp. Instituto Plantarum, Nova Odessa

Mendivelso HA, Camarero JJ, Royo Obregon O, Gutierrez E, Toledo M (2013) Differential growth responses to water balance of coexisting deciduous tree species are linked to wood density in a Bolivian tropical dry forest. PLoS ONE 8(10):e73855. https://doi.org/10. 1371/journal.pone.0073855

Mendivelso HA, Camarero JJ, Gutiérrez E, Zuidema EP (2014) Timedependent effects of climate and drought on tree growth in a Neotropical dry forest: Short-term tolerance vs. long-term sensitivity. Agricultural and Forest Meteorology 188:13-23. https://doi.org/ 10.1016/j.agrformet.2013.12.010

Mostacedo B, Justiniano MJ, Toledo M, Fredericksen T (2003). Guía Dendrológica de Especies Forestales en Bolivia, 231 pp. El país, 2da. Proyecto de Manejo Forestal Sostenible BOLFOR, Santa Cruz

Navarro G (2011) Clasificación de la Vegetación de Bolivia, 713 pp. Centro de Ecología Difusión Simón I. Patiño, Santa Cruz, Bolivia

Navarro G, Maldonado M (2004) Geografía Ecológica de Bolivia: Vegetación y Ambientes Acuáticos, 719 pp. Centro de Ecología Simón Patiño. Santa Cruz, Bolivia 
Pan Y, Birdsey RA, Fang J, Houghton R, Kauppi PE, Kurz WA, Phillips OL, Shvidenko A, Lewis SL, Canadell JG, Ciais P, Jackson RB, Pacala SW, McGuire AD, Piao S, Rautiainen A, Sitch S, Hayes D (2011) A large and persistent carbon sink in the world's forests. Science 333:988-993. https://doi.org/10.1126/science.1201609

Paredes-Villanueva K, Lopez L, Navarro Cerrillo RM (2016) Regional chronologies of Cedrela fissilis and Cedrela angustifolia in three forest types and their relation to climate. Trees 30:1581-1593. https://doi.org/10.1007/s00468-016-1391-8

Pumijumnong N (2013) Dendrochronology in Southeast Asia. Trees 27(2):343-358. https://doi.org/10.1007/s00468-012-0775-7

Rahman M, Islam M, Bräuning A (2019) Species-specific growth resilience to drought in a mixed semi-deciduous tropical moist forest in South Asia. Forest Ecology and Management 433:487-496. https:// doi.org/10.1016/j.foreco.2018.11.034

Rozendaal AMD, Zuidema AP (2011) Dendroecology in the tropics: a review. Trees 25:3-16. https://doi.org/10.1007/s00468-010-0480-3

Schöngart J (2008) Growth-oriented logging (GOL): a new concept towards sustainable forest management in Central Amazonian várzea floodplains. Forest Ecology and Management 256:46-58. https:// doi.org/10.1016/j.foreco.2008.03.037

Schulman E (1956) Dendroclimatic Changes in Semiarid America, 142 pp. University of Arizona Press, Tucson

Spracklen DV, Arnold SR, Taylor CM (2012) Observations of increased tropical rainfall preceded by air passage over forests. Nature 489 : 282-285. https://doi.org/10.1038/nature11390
Trouet V, Van Oldenborgh GJ (2013) KNMI Climate Explorer: a webbased research tool for high-resolution paleoclimatology. Tree-Ring Research 69(1):3-13. https://doi.org/10.3959/1536-1098-69.1.3

Urrutia R, Vuille M (2009) Climate change projections for the tropical Andes using a regional climate model: temperature and precipitation simulations for the end of the 21 st century. Geophysical Research Letters 114:D02108. https://doi.org/10.1029/2008JD011021

van der Sleen P, Groenendijk P, Vlam M, Anten NPR, Boom A, Bongers F, Pons TL, Terburg G, Zuidema ZA (2015) No growth stimulation of tropical trees by 150 years of $\mathrm{CO}_{2}$ fertilization but water-use efficiency increased. Nature geosctence 8:24-28. https://doi.org/ 10.1038/NGEO2313

Vieira-Aragão JR, Groenendijk P, Lisi CS (2018) Dendrochronological potential of four neotropical dry-forest tree species: climate-growth correlations in northeast Brazil. Dendrochronologia 53:5-16. https:// doi.org/10.1016/j.dendro.2018.10.011

Villalba R (1987) El árbol ante el clima y los años. Series científica 35: 44-47 https://www.mendoza.conicet.gov.ar/portal/ianigla/paginas/ index/publicaciones

Worbes M, Junk W (1999) How old are tropical trees? The persistence of a myth. IAWA 20:255-260. https://doi.org/10.1163/2294193290000689

Publisher's note Springer Nature remains neutral with regard to jurisdictional claims in published maps and institutional affiliations. 